Lisbon - Malacca Port Cities Twin Conferences 2019 / 2020

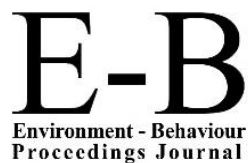

$$
\text { AicQoL2020Malacca }
$$

ASLI (Annual Serial Landmark International) Conferences on QoL2020

https://www.amerabra.org; https://fspu.uitm.edu.my/cebs; https://www.emasemasresources.com/

8th AMER International Conference on Quality of Life

Mahkota Hotel Melaka, Malacca, Malaysia, 18-19 Mar 2020

(Due to the Covid-19 lockdown, paper virtually presented on 25 Mar 2020)

\title{
Exploring Gender Differences in Complaint Behavior of Millennial Consumers
}

\author{
Azmi Mat ${ }^{1}$, Norliza Saiful Bahry ${ }^{1}$, Nur Liana Kori ${ }^{1}$, Zarina Abdul Munir ${ }^{2}$ \\ 1 Department of Marketing and Entrepreneurship Studies, \\ 2 Department of Management Studies, \\ Faculty of Business and Management, \\ Universiti Teknologi MARA Cawangan Selangor, Malaysia
}

azmimat@uitm.edu.my : nurliana2057@uitm.edu.my : norliz2956@uitm.edu.my : zarin453@uitm.edu.my Tel of 1 st Author:+60132791159

\begin{abstract}
Understanding and managing consumer's complaint behavior (CCB) is incredibly essential in the competitive business environment. This paper aims to investigate whether male and female millennial consumers differed in their complaint behavior and its aftermath. The study examines the moderation effect of gender on millennial's complaint behavior. The researchers distributed a total of 430 questionnaires to millennial consumers who have experienced a dissatisfaction episode within 12 months. The results show that gender was significantly associated with millennial's complaint behavior. These findings are generic across sex-type. This paper discusses the theoretical and managerial implications of the findings.
\end{abstract}

Keywords: Millennials; complaint behavior; gender; sex-type

eISSN: 2398-4287 @ 2020. The Authors. Published for AMER ABRA cE-Bs by e-International Publishing House, Ltd., UK. This is an open access article under the CC BYNC-ND license (http://creativecommons.org/licenses/by-nc-nd/4.0/). Peer-review under responsibility of AMER (Association of Malaysian Environment-Behaviour Researchers), ABRA (Association of Behavioural Researchers on Asians) and cE-Bs (Centre for Environment-Behaviour Studies), Faculty of Architecture, Planning \& Surveying, Universiti Teknologi MARA, Malaysia

DOI: https://doi.org/10.21834/e-bpj.v5i13.1952

\subsection{Introduction}

Understanding millennial's complaint behavior is essential in the present competitive business environment as it serves as quality improvement tools in enhancing customer's experience. The era during which customers took everything that was offered by the service providers is now gone. Today, customers are well and better educated. They are unwilling to compromise quality (Huang et al., 2003) and use various means to vent their disappointment that may break the business. Consumers, especially young workers, are demanding for the value of their monies. They are not hesitant to complain if they are not satisfied with the goods or services provided, or the response of the seller concerning their purchase; they are using the social media to express anger and frustration. The millennial generations present both opportunities and challenges to markets. Due to their familiarity and heavy users of technology and social media, millennials seem to be on a group of consumers who, when dissatisfied with a product or service or improper complaint handling, may retaliate on the internet. Therefore, the company will lose the opportunity to address a complaint, yet it will impact the organization's reputation and sales profit. In general, millennial consumers are those individuals born after 1980 who come of age 35 and below (Soares, 2017). Besides, it is estimated that this generation makes up $49.37 \%$ millennials in the year 2010 for the adult population who makes a complaint in social media. This generation, also known as the first generation to have grown up in a world saturated by networks of information, digital devices, and the promise of perpetual connectivity (Boys, 2010). Therefore, in this study, only respondents aged up to 35 years old will be selected to participate.

eISSN: 2398-4287 (C) 2020. The Authors. Published for AMER ABRA cE-Bs by e-International Publishing House, Ltd., UK. This is an open access article under the CC BYNC-ND license (http://creativecommons.org/licenses/by-nc-nd/4.0/). Peer-review under responsibility of AMER (Association of Malaysian Environment-Behaviour Researchers), ABRA (Association of Behavioural Researchers on Asians) and cE-Bs (Centre for Environment-Behaviour Studies), Faculty of Architecture, Planning \& Surveying, Universiti Teknologi MARA, Malaysia.

DOI: https://doi.org/10.21834/e-bpj.v5i13.1952 
In respect to gender and complaint behavior, Li (2010) explained that demographic characteristics such as age, income, and gender had been found to influence complaint behavior. Female consumers, for example, were found more likely to complain compared to male consumers (Keng et al., 1995). It is because complaints might, in particular, have negative consequences for women who have been traditionally stereotyped as complainers. Heung and Lam (2003) supported by the current study, where they found that female Hong Kong Chinese consumers were more likely to voice their dissatisfaction than male counterparts. Thus, this paper aims to investigate whether male and female millennial consumers differed in their complaint behavior and its aftermath. The study also will examine the moderation effect of gender on millennial's complaint behavior.

\subsection{Literature Review}

Prior research in consumer complaint behavior began to generate attention from the researchers in marketing research fields during the 1970s. Most of the studies of complaint behavior have been conducted in industrialized western countries where consumerism activity is an accepted phenomenon (Kaynak et al., 1992). Besides, most studies on complaint behavior also were conducted in the United States during the 1970s and 1980s (Hunt, 1977). To date, only a few studies concerning millennial's complaint behavior have been undertaken in South-East Asia. The first study conducted by Keng et al., (1995) attempts to profile complaint behavior of Singaporean and followed by the study that carried out by Phau and Sari (2004) which attempts to investigate why some people tend to complain while others do not, among Indonesian consumers in general. In 2017, Zhang et al. conducted a study to examine Generation Y's positive and negative word of mouth in social media and mobile technology. Besides, another study was conducted by Soares et al., 2017 to examine generational differences in the complaint and post-recovery behaviors after service failures and recoveries. It is believed that generational differences also appear to affect people's tendency to complaint (Homburg and Giering, 2001). Although their consumption behaviors have received tremendous attention from the organizations, very little research has focused on this particular group (Zhang et al., 2017). Thus, this study is conducted to explore about millennial's complaint behavior.

\subsection{Gender Differences in Complaint Behavior.}

Demographic variables have been found to influence the consumer's complaint behavior besides other factors, such as attitude, knowledge, and personality. Li (2010), for example, explained that demographic characteristics have a significant influence on the consumer's complaint behavior, including age, income, gender, and social status. Researchers in this field, conducting a study related to consumer complaint behavior, always examine these variables. Also, demographic factors are perceived to good indicators of complaining behaviors (Boote, 1998; Volkov et al., 2002; Heung and Lam, 2003; Ndubisi and Ling., 2007). Previous literature also has shown that consumer complaint behavior varies by demographic characteristics.

Prior research found that females were more likely to complain compared to their counterparts (Keng et al., 1995). This statement was supported by a study conducted by Heung and Lam (2003), that female consumers were more likely to voice their dissatisfaction than male counterparts. Additionally, previous studies also confirmed that negative terms associated with complaining, such as nagging, bitching, and whining are stereotyped as female behavior (Conway and Vartanian, 2000). Male consumers tend not to complain when they experience a service failure, at least not about little things. This is because males have been taught since they were little boys to be tough, to be endured, to be stoic, to be unemotional, and to hold it in order to be men. In other words, men have been taught that is not manly to the complaint. Consequently, men have little tolerance for any complaining (Oh, 2005). However, in contrast, female consumers are more inclined to the complaint (Keng et al., 1995), and therefore this study predicts:

$\mathrm{H} 1$ : There is a relationship between attitude and millennial's complaint behavior.

$\mathrm{H} 2$ : There is a relationship between knowledge and millennial's complaint behavior.

$\mathrm{H} 3$ : There is a relationship between personality and millennial's complaint behavior.

$\mathrm{H} 4$ : There is a significant difference in complaint behavior between males and females.

\subsection{Methodology}

A total of 430 questionnaires were distributed at the selected service centers. Respondents were given a screening question before they can participate in this study. Only those respondents who have experienced a dissatisfaction episode within 12 months will be considered to provide their feedback. Another criterion is those who seek redress directly or complain to the third party been selected to proceed. Besides, only respondents aged up to 35 years old were chosen to provide their responses. The researchers adapted the seven items measurement of attitude, nine items of personality from Keng et al., (1995). The seven items of knowledge also have been adapted from Zhao and Md Nor Othman (2010), and ten items of complaint behavior were adapted form Alfansi and Atmaja (2011) and Ekiz and Au (2009). A manager of the service center had given prior permission for the data collection. Out of 430 , there survey returned rate were 400 surveys where the 30 surveys considered not completed. Table 1 shows the profile of the customers. 
Table 1 : Customer's Profile

\begin{tabular}{|c|c|c|c|}
\hline Demographic & & Frequency (n) & Percentage (\%) \\
\hline \multirow{2}{*}{ Gender } & Male & 158 & 39.5 \\
\hline & Female & 242 & 60.5 \\
\hline \multirow{8}{*}{ Qualification of Education } & LCE/PMR/SRP & 1 & 3 \\
\hline & MCE/SPM/SPMV & 18 & 4.5 \\
\hline & STPM & 4 & 1.0 \\
\hline & Matriculation & 3 & 0.8 \\
\hline & Diploma & 58 & 14.5 \\
\hline & Bachelor's degree & 220 & 55.0 \\
\hline & Master & 94 & 23.5 \\
\hline & PHD & 2 & 0.5 \\
\hline \multirow{8}{*}{ Personal Income } & Below RM1000 & 28 & 7.0 \\
\hline & RM1001-RM2000 & 48 & 12. \\
\hline & RM2001-RM3000 & 155 & 38.8 \\
\hline & RM3001-RM4000 & 95 & 23.8 \\
\hline & RM4001-RM5000 & 61 & 15.3 \\
\hline & RM5001-RM6000 & 8 & 2.0 \\
\hline & RM6001-RM7000 & 1 & 0.3 \\
\hline & RM7000 and above & 4 & 1.0 \\
\hline
\end{tabular}

\subsection{Results and Discussion}

The measures of attitude in the questionnaire were adapted to previous research in the areas of customer satisfaction and complaining behavior (Keng, Richmond, and Han, 1995). Additionally, the seven items of knowledge also have been adapted from Zhao and Md Nor Othman (2010) and ten items of complaint behavior adapted from Alfansi and Atmaja (2011) and Ekiz and Au (2009). As shown in Table 2, all the items tested were measure based on five Likert scales. In further data analysis, partial least square has been used to analyze the causal relationship between attitude, knowledge, personality, and complaint behavior.

Table 2: Items Measurement

\begin{tabular}{|c|c|}
\hline \multicolumn{2}{|c|}{ Attitude } \\
\hline C1_A & I always complaint when l'm dissatisfied because it's my right \\
\hline C2_A & I find it is not embarrassing to the complaint \\
\hline C3_A & I feel uncomfortable if not complaint directly about dissatisfactory service to the company \\
\hline C4_A & I feel obliged to complain directly about dissatisfactory service to the company \\
\hline C5_A & Complaining about an unsatisfactory service is my duty \\
\hline C6_A & I complain because I confident that the company would handle and resolve my problem \\
\hline C7_A & I feel a sense of accomplishment when I have managed to get a complaint to a company take care of satisfactorily \\
\hline \multicolumn{2}{|c|}{ Knowledge } \\
\hline C1_K & My rights as a consumer \\
\hline $\mathrm{C} 2 \_\mathrm{K}$ & Knowledge about the technical matter and products \\
\hline C3_K & I know where to complaint if I am dissatisfied with the service offered \\
\hline C4_K & I know that I also can lodge my complaint to Tribunal for Consumer Claims in order to get an appropriate and quick response \\
\hline C5_K & Knowledge about the procedures that I need to follow, if I decide to lodge my complaint with Tribunal for Consumer Claims \\
\hline C6_K & I know pretty much about the provisions provided in the Consumers' Protection Act, 1999 \\
\hline C7_K & I know about the remedies that I can claim if I choose to lodge my complaint with Tribunal for Consumer Claims \\
\hline
\end{tabular}


Mat, A., et.al. / $8^{\text {th }}$ AicQoL2020Malacca, Mahkota Hotel Melaka, Malacca, Malaysia, 18-19 Mar 2020 / E-BPJ, 5(13), Mar 2020 (pp.47-54)

\begin{tabular}{|c|c|}
\hline \multicolumn{2}{|c|}{ Personality } \\
\hline C1_P & I always stand up for what I believe \\
\hline C2_P & I don't like to leave everything to fate \\
\hline C3_P & I complain because I think, it is not a scene and embarrass myself \\
\hline C4_P & I would attempt to notify the company if I thought service was particularly bad \\
\hline C5_P & I like to receive attention \\
\hline C6_P & I like to be different from others \\
\hline C7_P & I have more self-confident than most people \\
\hline C8_P & I do not hesitate to a complaint if I think it is warranted to do so \\
\hline C9_P & I am confident in my ability to the complaint \\
\hline \multicolumn{2}{|c|}{ Complaint Behavior } \\
\hline D1 & When I'm not satisfied with the services, I will voice my complaint to the organization in the following service encounter \\
\hline D2 & When I feel dissatisfied with the services offered, I will discuss the problem with the manager or representative of the firm \\
\hline D3 & I always asked the seller for repairs, replacement or refund \\
\hline D4 & I always asked the firm to take care of the problem \\
\hline D5 & I complain to someone in charge when I feel dissatisfied \\
\hline D6 & I lodge my complaint in the electronic environment (email, facebook or twitter) of the company \\
\hline D7 & I lodge my complaint with the legal representative (Law Firm) letter to the press about the poor service 10 \\
\hline D8 & I lodge my complaint to Consumer Association (NCCC, FOMCA and other consumers agency) \\
\hline D9 & I would write to the press about the poor service \\
\hline D10 & I would complain to the tribunal \\
\hline
\end{tabular}

In order to confirm the model, this research used the structural equation modeling (SEM) technique using partial least squares (PLS) with SmartPLS 3.0 (Ringle et al., 2005) software. SmartPLS is a second-generation analysis software that can be used to test a complex model with latent variables. The reflective measurement model was tested at first stages to validate the instrument used, followed by structural model testing to test the hypotheses testing. For reflective constructs, the indicator loadings, reliabilities, and AVE are used to assess convergent validity. As shown in Table 3, the measurement model revealed all the factor loading of the items tested was more significant than 0.5 , which means that the items were relevant and present the constructs tested.

On the other hand, the composite reliability (CR) for all constructs tested was highly reliable as the values of $\mathrm{CR}$ were more significant than 0.7 (Hair et al., 2014). Additionally, the value was the average variance extracted (AVE) showed that all construct was more significant than 0.5 . With CR and AVE values were meet the threshold values, the construct of this study indicated acceptable for the model of this study.

Table 3: Reflective Measurement Model

\begin{tabular}{|l|c|c|c|c|}
\hline \multirow{4}{*}{ Constructs } & Items & Item Loading & $\begin{array}{c}\text { Composite } \\
\text { Reliability (CR) }\end{array}$ & $\begin{array}{c}\text { Average } \\
\text { Variance } \\
\text { Extracted (AVE) }\end{array}$ \\
\hline \multirow{5}{*}{ Attitude } & C1_A & 0.836 & 0.916 & 0.611 \\
\hline & C2_A & 0.771 & & \\
\hline & C3_A & 0.734 & & \\
\hline & C4_A & 0.841 & & \\
\hline & C5_A & 0.819 & & \\
\hline & C6_A & 0.713 & & \\
\hline & C7_A & 0.746 & & \\
\hline \multirow{5}{*}{ Personality } & C1_P & 0.83 & 0.892 & 0.504 \\
\hline & C2_P & 0.712 & & \\
\hline & C3_P & 0.75 & & \\
\hline & C4_P & 0.816 & & \\
\cline { 2 - 6 } & & & & \\
\hline
\end{tabular}




\begin{tabular}{|l|c|c|c|c|}
\hline \multirow{5}{*}{} & C5_P & 0.287 & & \\
\hline & C6_P & 0.273 & & \\
\hline & C7_P & 0.68 & & \\
\hline & C8_P & 0.84 & & \\
\hline & C9_P & 0.888 & & \\
\hline \multirow{5}{*}{ Knowledge } & C3_K & 0.527 & 0.869 & 0.576 \\
\hline & C4_K & 0.694 & & \\
\hline & C5_K & 0.854 & & \\
\hline & C6_K & 0.82 & & \\
\hline & C7_K & 0.849 & & \\
\hline \multirow{5}{*}{ Consumer Complaint Behaviour } & D1 & 0.697 & 0.835 & 0.508 \\
\hline & D2 & 0.806 & & \\
\hline & D3 & 0.745 & & \\
\hline & D4 & 0.756 & & \\
\hline & D7 & 0.528 & & \\
\hline & D 2 D10 & & \\
\hline
\end{tabular}

Note: D5, D6, D8, D9 \& D10 were deleted due to low loading

\subsection{Discriminant Validity}

Discriminant validity concerns the degree to which the measures of different constructs are distinct from one another and is assessed by comparing the correlations between constructs with the square root of the AVE for a construct (Fornell \& Larcker, 1981). Table 4 presents the discriminant validity of the measurement model. The elements in the matrix diagonals, representing the square root of the AVEs, are more exceptional in all cases than the off-diagonal elements in their corresponding row and column, indicating discriminant validity has achieved. The result showed there were no issues with the discriminant validity of this study.

Table 4: Discriminant Validity

\begin{tabular}{|l|l|l|l|l|}
\hline Constructs & 1 & 2 & 3 & 4 \\
\hline 1.Attitude & $\mathbf{0 . 7 8 1}$ & & & \\
\hline 2.Complaint Behavior & 0.435 & $\mathbf{0 . 7 1 2}$ & & \\
\hline 3.Knowledge & 0.393 & 0.461 & $\mathbf{0 . 7 1 8}$ & \\
\hline 4.Personality & 0.778 & 0.373 & 0.392 & $\mathbf{0 . 7 1}$ \\
\hline
\end{tabular}

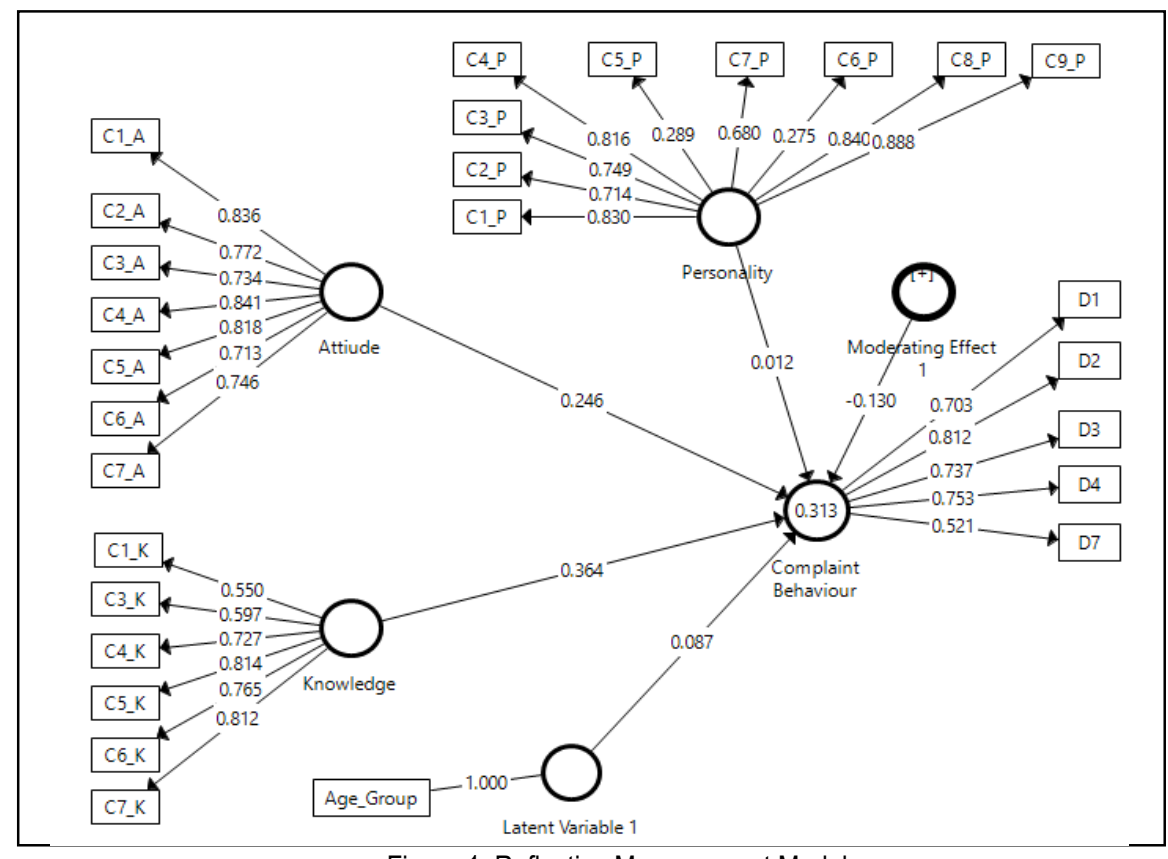

Figure 1: Reflective Measurement Model 


\subsection{Structural Model}

The bootstrapping procedure was applied to generate the path coefficients and their corresponding t-values, which then enabled inferences to be made by determining the statistical significance of each path coefficient. The results were presented in Figure 2 revealed that the R2 value was 0.304 , suggesting that 30.4 percent of the variance in complaint behavior could be explained by attitude, knowledge, and personality. As shown in Table 5, there was a positive and significant relationship between attitude $(\beta=0.246, p<0.05)$, knowledge $(\beta=0.364, p<0.05)$, and complaint behavior except for personality $(\beta=0.246, p>0.05)$ found there was not significant in this study. Thus, only hypotheses $\mathrm{H} 1$ and $\mathrm{H} 2$ were supported in this study, while $\mathrm{H} 3$ was not supported.

The effects size as suggested by Cohen (1988), attitude $(\mathrm{f} 2=0.03$ ) and personality $(\mathrm{f} 2=0.122)$ which are considered small. On the other hand, the effect size of knowledge is considered as medium ( $\mathrm{f} 2=0.152)$. Those results confirmed by assessing confidence interval bias, which measures the lower and upper limit values. There is zero value straddle between lower and upper limits. The result revealed there is no significant relationship between the constructs tested. The result revealed the attitude has no zero values straddles in between lower and upper limits $(L L=0.116, U L=0.431)$, followed by knowledge $(L L=0.246, U L=0.452)$. The resulting contrast with personality $(L L=-0.187, U L=0.170)$ where there are values of zero straddle in between of personality and complaining behavior. Hence, the result confirmed that there is no relationship between those constructs tested. Figure 2 shows all path coefficients and their corresponding tvalues.

Additionally, the fourth hypothesis was to test the moderating effects of gender. To test this hypothesis, this used the productindicator approach, as suggested by Henseler and Fassott (2010). The interaction term had created between attitudes and complaining behavior. When the interaction effect was entered into the model, the R2 increased to 0.350 , giving an R2 change of 4.6 percent. The interaction effect was significant $(\beta=0.043, p<0.5)$ however the effects size as suggested by Cohen (1988), was small effect (f2 = 0.026 ) on the relationship. Besides, there is no zero value straddle between lower and upper limits ( $L L=-0.221, U L=-0.044)$ in the moderating effects. Therefore, hypothesis 4 was supported by this study.

Table 5: Structural Model

\begin{tabular}{|l|c|c|c|c|c|c|c|}
\hline Relationships & Beta Value & SE & T-Values & P Values & $F^{2}$ & LL & UL \\
\hline Attitude $>$ Complaint Behavior & 0.246 & 0.079 & 3.108 & 0.002 & 0.033 & 0.116 & 0.431 \\
\hline Knowledge -> Complaint Behavior & 0.364 & 0.052 & 7.001 & 0 & 0.152 & 0.246 & 0.452 \\
\hline Personality -> Complaint Behavior & 0.012 & 0.086 & 0.134 & 0.894 & 0.102 & -0.187 & 0.170 \\
\hline Attitude->Gender->Complaint Behavior & -0.13 & 0.043 & 3.046 & 0.002 & 0.026 & -0.221 & -0.044 \\
\hline
\end{tabular}

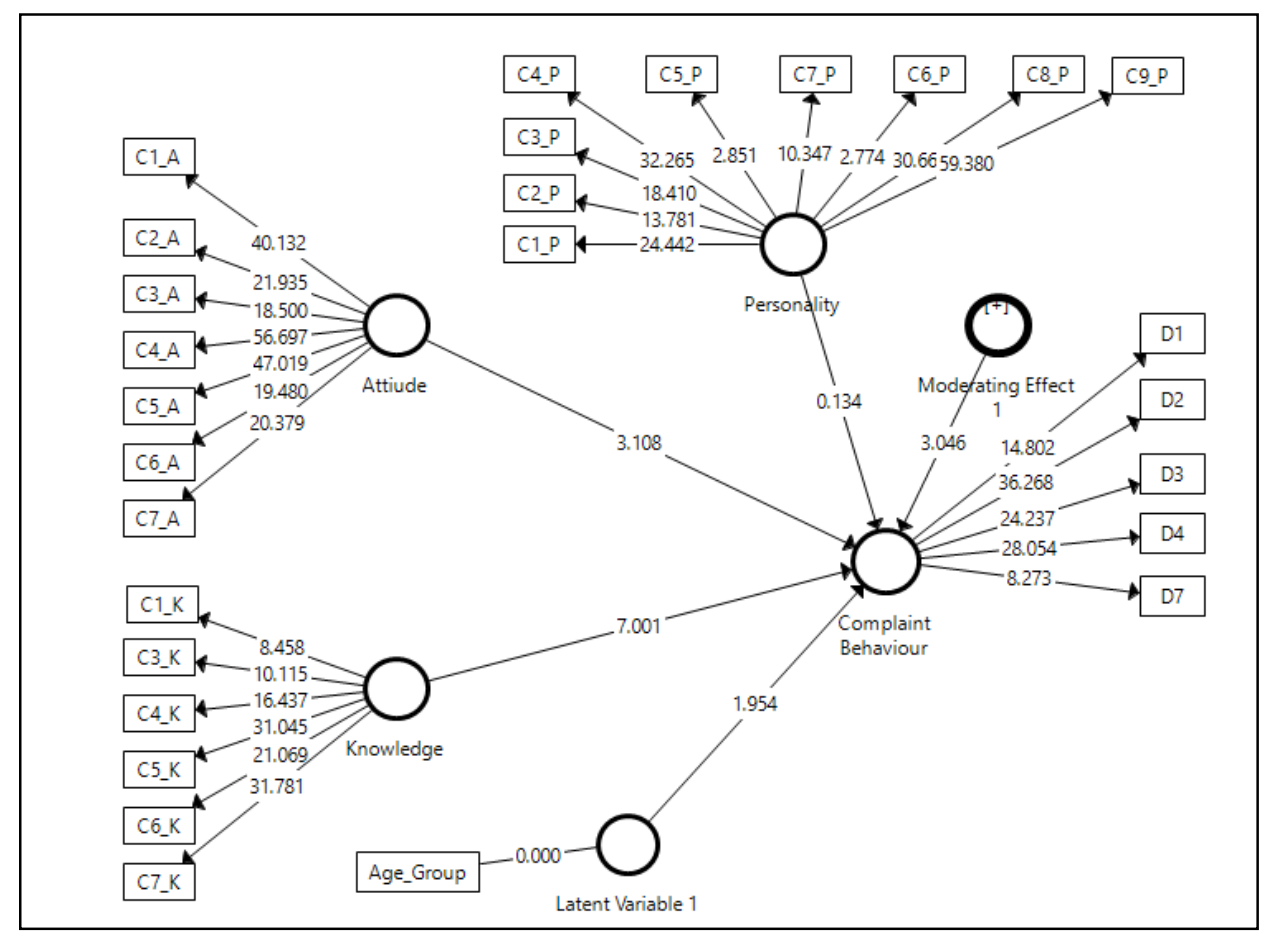

Figure 2: Structural Model 


\subsection{Conclusions}

Most previous studies in consumer complaint behavior have focused on the consumer in general. Very few studies conducted focusing on complaint behavior among millennials consumers. Millennials have the global purchasing power of more than USD200 billion annually from 2017, about a third of the global total and USD10 trillion in their lifetime. This fact clearly shows the importance of millennials' contribution to the organization's sustainability as well as the economic growth of the country.

From a practical point of view, companies or marketers should pay special attention to the need of consumers who are females and better educated. The findings demonstrated that, demographically, millennial consumers' complaint behavior was not different from their counterparts in the United States, Western countries, and other Asian countries. Also, concerning the main objective of the study, the product-indicator approach has been employed. The results indicated that millennial consumer's complaint behavior varies according to gender. This finding is consistent with those prior research (for instance, Moyer, 1985; Bettina et al., 1991; Hansen and Wooldridge, 2002; Phau and Sari., 2004).

However, certain limitations of the study are worth to be noted. First, the finding is limited to the specific sample. The restriction of the sample only gathered among millennial consumers in the Shah Alam area. It minimized the generalizability of the results. Future studies are needed to examine the proposed framework in a broader range that might include millennial consumers in other states in Malaysia.

\section{Acknowledgments}

The authors gratefully acknowledge the help of the Institute of Research Management and Innovation, Universiti Teknologi MARA, in providing the Lestari Grant (Project Number: =600-IRMI/Dana KCM 5/3/LESTARI (199/2017). The authors are also thankful to all respondents who have participated in this study.

\section{References}

Alfansi, L., and Atmaja, F.T. (2011). Service failure and complaint behavior in the public hospital industry: The Indonesian experience. Journal of Non-Profit and Public Sector Marketing. 21: 309-325.

Boote, J. (1998). Towards a comprehensive taxonomy and model of consumer complaining behavior. Journal of Consumer

Boys, S.K. (2010). The Millennials refuse to be ignored! An analysis of how the Obama Administration furthers the political engagement of a new generation. International Journal of Public Participation. 4(1): 31-42.

Cohen,J., (1988). Statistical Power Analysis for the Behavioral Sciences. Mahwah, NJ: Lawrence Erlbaum.

Conway, M., and Vartanian, L.R. (2000). A status account of gender stereotypes: beyond communality and agency. Sex Roles. 43: 181-199.

Ekiz, H.E., and Au.N. (2009). Issues and opportunities of internet hotel marketing in developing country. Journal of Travel, Tourism Marketing (SSCI Journal). 26(3): 2252243

Fornell, C., \& Larcker, D. F. (1981). Evaluating structural equation models with unobservable variables and measurement error. Journal of Marketing Research, 18, 3950 .

Hair, J.F., Hult, G. T. M., Ringle, C. M., \& Sarstedt, M. (2014). A Primer on Partial Least Squares Structural Equation Modelling. Thousand Oaks, CA: SAGE.

Homburg, C. and Giering, D. (2009). Personal characteristics as moderators of the relationship between customer satisfaction and loyalty - an empirical analysis. Psychology and Marketing. 18(1): 43-66.

Heung, V.C.S. and Lam, T. (2003). Customer complaint behavior towards hotel Restaurant services. International Journal of Hospitality Management. 15(5): 283-289.

Hunt, H.K. (1977). Conceptualization and Measurement of Consumer Satisfaction and Dissatisfaction. Boston: Marketing Sciencelnstitute, Harvard University.

Kaynak, E., Kucukemiroglu, O. and Odabasi, Y. (1992). Consumer complaint handling in an advanced developing country: An empirical investigation. Journal of Business Ethics. 11(11): 813.

Keng, K.A, Richmond, D., and Han, S. (1995). Determinants of consumer complaint behavior: A study of Singapore consumers. Journal of International Consumer Marketing. 8 (2): 101-111.

Lam, T. and Tang, V. (2003). Recognizing customer complaint behavior: The case of Hong Kong hotel restaurants. Journal of Travel and Tourism Marketing.14(1):69-86.

Li, M. (2010). Exploration of Chinese Consumer Complaint Behavior in the Hospitality Industry. University of Nevada Las Vegas, Professional Paper.

Ndubisi, N.O and Ling, T.Y. (2007). Evaluating gender differences in the complaint of Malaysian consumer. Asian Academy of Management Journal. 12(2): 1-13.

Oh, D. (2005) Complaining intentions and their relationship to complaining behavior of academic library users in South Korea. Library Management.27(3): 16.

Phau, I. and Sari P.R. (2004). Engaging in Complaint Behavior: An Indonesian Perspective. Marketing Intelligence and Planning. $22(4)$ : $407-426$. 
Soares, R.R., Zhang, T.T., Proenca, J.F., and, Kandampully, J. (2017). Why are Generation Y consumers the most likely to complain and repurchase. Journal of Service Management. 28(3): 520-540.

Volkov, M., Summers, J. and Morgan, M.J. (2005). Consumer complaint behavior in sport consumption: A theoretical model, ANZMAC, University of Southern Queensland.

Zhang, T., Behzad Abound Omran, and, Cobanoglu, Cihan. (2017). Generation Y's positive and negative eWOM: Use of social media and mobile technology. International Journal of Contemporary Hospitality Management. 29(2017): 732-761.

Zhao, W., and Md Nor Othman. (2010). The influence of knowledge of consumer protection and perception of marketing factors on consumer complaint behavior: A study of Malaysia consumers. OIDA International Journal of Sustainable Development. 1(9): 27-35. 